\title{
Jalostusvalinnan ja sukupuolen vaikutus lihasikojen osteokondroosiin
}

\author{
Maija Karhapää1), Hilkka Siljander-Rasi' ${ }^{1)}$, Tiina Kortelainen ${ }^{1)}$, Marja-Liisa Sevón-Aimonen ${ }^{2)}$ \\ 1) Luonnonvarakeskus, Liha- ja non-food eläintuotanto, Koetilantie 5, 0790 Helsinki \\ 2) Luonnonvarakeskus, Liha- ja non-food eläintuotanto, Humppilantie 14, 31600 Jokioinen \\ etunimi.sukunimi@luke.fi
}

Jalkaheikkous on hyvin yleinen sikojen hyvinvointiongelma ja se aiheuttaa sianlihan tuottajille taloudellista vahinkoa. PROHEALTH-hankkeen tavoitteena on löytää keinoja, joiden avulla voidaan vähentää sikojen jalkaheikkoutta ja nivelvaurioita (osteokondroosia). Tässä lihasikakokeessa tutkittiin erilaisten jalostustavoitteiden ja sukupuolen yhteyksiä sikojen jalkaheikkouteen ja osteokondroosin esiintymiseen.

Tutkimuksessa käytettiin Figen Oy:n eläinaineksen sikoja ja selvitettiin kahden maatiaisrotuisen jalostuslinjan (Matriarkka tai Muskeli) ja sukupuolen (karju tai imisä) vaikutusta jalkaheikkouden ja osteokondroosin esiintymiseen. Jalostuslinjat muodostettiin samasta populaatiosta vanhempiensa keskimääräisten jalostusindeksien perusteella. Matriarkkalinjan sikojen vanhemmilla oli korkea H-indeksi (hedelmällisyys) ja Muskelilinjan sikojen vanhemmilla oli korkea K-indeksi (tuotanto-ominaisuudet ja teuraslaatu).

Lihasikakokeessa 135 sikaa kasvatettiin 40 kg alkupainosta 120 kg loppupainoon. Siat kasvatettiin 11 sian karsinoissa sukupuolet erillään. Sioilla oli 5-vaiheinen yksilöllinen ruokinta (ad libitum), joka oli suunniteltu täyttämään jalostukseen kasvavien karjujen ravinnontarve. Sikojen sorkkien rakenne ja jalkojen virheasennot arvioitiin ja sioille tehtiin kävelytesti noin viikkoa ennen teurastusta. Verinäytteistä testattiin seerumin D-vitamiinin, fosforin, kalsiumin ja alkalisen fosfataasin pitoisuudet. Reisi- ja olkaluiden $(\mathrm{n}=270)$ nivelpintojen osteokondroosimuutokset luokiteltiin silmämääräisesti asteikolla 0-5 ( $0=$ ei muutoksia). Polvi- ja kyynärnivelten osteokondroosimuutokset luokiteltiin myös arvioimalla nivelestä sahattujen viipaleiden pinnat. Sian sorkan luista määritettiin ominaispaino ja murtolujuus. Tilastollinen malli sisälsi kiinteinä tekijöinä jalostuslinjan, sukupuolen, linja*sukupuolen ja satunnaisina tekijöinä erän, isän, pahnueen hierarkkisesti ja isän alla.

Matriarkka- ja Muskelilinjojen siat kasvoivat keskimäärin 901 ja 870 g päivässä, rehuhyötysuhde oli 26.1 ja 25.8 MJ NE kg-1 ja lihaprosentti 62.8 ja 63.5\% (P> 0.10). Jalostuslinjojen tai sukupuolten välillä ei ollut eroa jalkaheikkoudessa. Polvinivelen siivujen osteokondroosimuutosten jakaumassa ei ollut eroa jalostuslinjojen välillä, mutta karjuilla oli enemmän vakavampia osteokondroosimuutoksia kuin imisillä ( $\mathrm{P}<0.02)$. Koko aineistoa tarkastellessa suurimmassa osassa (47.1\%) kyynärnivelen nivelpinnoista oli osteokondroosiin viittaavia muutoksia (luokka 2). Vain 1.2\% kyynärnivelen nivelpinnoista luokiteltiin normaaleiksi. Olkaluiden nivelpintojen osteokondroosimuutokset olivat vakavampia kuin reisiluiden nivelpintojen osteokondroosimuutokset. Tulokset osoittavat, että osteokondroosi on yleinen suomalaisilla maatiaisrodun sioilla ja karjuilla on enemmän osteokondroosia kuin imisillä. PROHEALTH-hanke on saanut rahoitusta Euroopan Unionin seitsemännestä tutkimuksen puiteohjelmasta (sopimusnro 613574).

Asiasanat: sika, osteokondroosi 


\section{Johdanto}

Eläinten tuotantosairaudet heikentävät eläinten hyvinvointia, tuotteiden laatua ja tuotannon kannattavuutta. Sairaudet myös kuormittavat ympäristöä, kun antibioottien käyttö ja eläinten kuolleisuus lisääntyvät ja tuottavuus huononee. Tämä tutkimus toteutettiin osana kansainvälistä ProHealth-hanketta, jonka tavoitteena on sika- ja siipikarjatuotannon kestävyyden ja kannattavuuden sekä eläinten hyvinvoinnin parantaminen erilaisia tuotantosairauksia vähentämällä ja ennaltaehkäisemällä.

Jalkaheikkous on hyvin yleinen sikojen hyvinvointiongelma ja se aiheuttaa myös taloudellista vahinkoa sianlihan tuottajille (Nalon ym. 2013). Jalkaheikkous ei ole yksiselitteinen sairaus, vaan sen taustalla on yleensä useita syitä, kuten perinnölliset tekijät, niveltulehdukset, tapaturmaiset vauriot ja osteokondroosi (Nakano ym. 1987, Jensen ja Toft 2009). Osteokondroosia pidetään tärkeimpänä jalkaheikkoutta aiheuttavana tekijänä. Noin puolella sioista voi olla joitain tavallisesti lieviä, osteokondraalisia vaurioita nivelissään (Jørgensen ja Andersen 2000). Aikaisemmassa suomalaisessa tutkimuksessa (Storskrubb ym. 2010) osteokondroosiin viittaavia vaurioita oli maatiaisrodun sioilla olkanivelessä $29 \%$ ja polvinivelessä $31 \%(n=464)$.

Osteokondroosi on luun ja ruston kasvu- ja kehityshäiriö, jossa nivelalueen luutuminen häiriintyy ja vaurioalueen verenkierto heikkenee tai estyy (Nakano ym. 1987, Ytrehus ym. 2007). Rusto paksuuntuu aluksi häiriökohdasta, syntyy tulehdusalue ja vähitellen rustokudos irtoaa alla olevasta luusta. Tilanne voi johtaa rustokappaleen irtoamiseen nivelen sisään (osteocondrosis dissecans=OCD) (Nakano ym. 1987, Ytrehus ym. 2007). Sioilla osteokondroosia esiintyy eniten kyynär- ja polvinivelissä, mutta sitä on myös olka-, lonkka-, ja kinnernivelissä sekä lantion ja selkärangan nivelissä (Reiland 1975). Epäsäännöllinen ruston pinta tai halkeama (OCD) on helposti silmämääräisesti havaittava ja se on siten helppo diagnosoida teurastetun eläimen nivelestä (Reiland 1975). Sen sijaan nivelruston paksuuntuminen tai rustossa ja ruston alla olevat vauriot voidaan havaita vain silloin kun rusto ja luu on sahattu siivuiksi (Busch ja Wachmann 2011).

Tämän lihasikakokeen tavoitteena oli selvittää eläinaineksen (Figen Oy:n kahden maatiaisrotuisen jalostuslinjan, Matriarkka tai Muskeli) ja sukupuolen (karju tai imisä) vaikutus tuotantotuloksiin, jalkaheikkouteen ja osteokondroosin esiintymiseen.

\section{Materiaali ja menetelmät}

Lihasikakoe alkoi 24.10.2014 Figen Oy:n tutkimusasemalla Längelmäellä ja päättyi 31.7.2015. Koska kokeessa otettiin sioilta verinäytteitä, kokeella oli hankelupa eläinkoelautakunnalta (ESAVI/7870/04.10.07/2014). Kokeessa käytettiin kahden maatiaisrotuisen jalostuslinjan (Matriarkka tai Muskeli) sikoja ( $\mathrm{n}=135)$. Jalostuslinjat muodostettiin samasta populaatiosta vanhempiensa keskimääräisten jalostusindeksien perusteella. Matriarkkalinjan sikojen vanhemmilla oli korkeampi hedelmällisyysindeksi (H-indeksi $\geq 110)$ kuin tuotanto-ominaisuuksia ja teuraslaatua kuvaava K-indeksi (Kindeksi $\leq 110$ ). Muskelilinjan sikojen vanhemmilla oli korkeampi K-indeksi kuin H-indeksi (K-indeksi $\geq 110, \mathrm{H}$-indeksi $\leq 110$ ). Matriarkka linjan sikoja oli kokeessa 74 ja Muskelilinjan sikoja $61 \mathrm{kpl}$.

Siat kasvatettiin 11 sian karsinoissa sukupuolet erillään (62 imisää 73 karjua). Sikojen keskimääräinen alkupaino kokeessa oli 39.8 kg (SD 7.33) ja loppupaino 119.9 kg (SD 13.0). Koesikoja oli karsinoissa 1-11 kpl ja muut karsinan siat olivat koeaseman sikoja. Sioilla oli 5-vaiheinen kuivarehu ruokinta (ad libitum) Spotmix (MLP, Schauer Electronic, Germany) ruokinta-automaatilla (1 automaatti/karsina). Sikojen ruokinta oli optimoitu täyttämään jalostukseen kasvavien karjujen ravinnontarve. Teurastamolta sikojen ruhoista saatiin lihaprosentti ja teuraspaino.

Kokeessa seurattiin sikojen kasvua ja rehuhyötysuhdetta. Noin viikkoa ennen teurastusta (koeviikolla 12, paino n. $115 \mathrm{~kg}$ ) arvioitiin sikojen liikuntakyky, sorkkien rakenne ja jalkojen virheasennot Serenius ym. (2001) mukaan. Liikuntakyvyn arvioinnin asteikko oli: 5) erinomaiset, 4) hyvät, 3) tyydyttävät, 2) välttävät ja 1) huonot jalat. Samalla merkittiin ylös etu- ja takajalkojen rakenneviat. Samalla tarkastelukerralla sioille tehtiin myös käyttäytymistä tarkkaileva ontumistestaus Main ym. (2000) mukaan. Tässä arvostelussa asteikko oli $0-5$, jossa 0 tarkoittaa, että sika seisoo normaalissa asennossa, kävelee ja käyttäytyy normaalisti. Luokka 5 tarkoittaa, että sialla on vakavia ongelmia liikkumisessa, eikä se pysty kunnolla seisomaan. Main ym. (2000) testaukseen kuuluvat seuraavat osa-alueet: välitön reagointi 
ihmiseen, yksilön käyttäytyminen ryhmässä, reagointi portin aukaisun jälkeen, seisoma-asento ja käynti (kävely). Osa arviointikriteereistä oli painotettuja ja ne ratkaisivat ontumisen yleisarvosanan. Yksilön käyttäytymistä ryhmässä sekä kävelykykyä tyhjässä karsinassa tarkkailtiin tässä kokeessa 5 minuutin ajan.

Paikallinen eläinlääkäri otti sioista verinäytteet kaulalta vena cephalica - laskimosta vakuumitekniikalla muutamaa päivää ennen teuraaksi menoa (koeviikko 12-13). Näytteet otettiin aamulla yön yli kestäneen paaston jälkeen (12-14 tuntia). Verinäytteistä testattiin seerumin D-vitamiinin (25-OH D3, määritys HPLC, IDEXX Laboratories Oy), fosforin (epäorgaaninen P, Pi, fosfomolybdaattina UV-fotometrisesti, Daly ja Ertigshausen 1972), kalsiumin (Ca, kolorimetrinen menetelmä, arsenazo III, Janssen ja Helbing, 1991) ja alkalisen fosfataasin pitoisuudet (AFOS, ALP alkaline phosphatase, EC 3.1.3.1, IFCC 1983/4). Teurastamolta saatiin nivelten osteokondroosimuutosten arvioimiseksi näytteiksi 111 oikeaa reisiluuta ja 84 oikeaa olkaluuta, joista yksi oli nivelpinnoiltaan vajavainen (ei arvosteltu). Reisiluiden ja olkaluiden nivelien osteokondroosimuutoksia arvioitiin kahdella menetelmällä. Nivelpintoja arvioitiin silmämääräisesti Busch ja Wachmann (2011) ja van Grevenhof ym. (2011) käyttämällä menetelmällä. Tässä menetelmässä nivelen rustopintojen vaurioiden luokitus oli nollasta viiteen, jossa 0 tarkoittaa normaalia vauriotonta nivelpintaa, luokka 1 tarkoittaa ohentunutta nivelrustoa, luokassa 2 nivelruston pinnalla on havaittavissa epäsäännöllisyyksiä, luokassa 3 nivelruston pinnassa on laajoja tai syviä vaurioita ja luokassa neljä on laajoja eroosioalueita tai haavaumia nivelrustossa. Luokassa 5 nivelrusto on rikki ja nivelrustossa on irrallinen läppä ( $\mathrm{OCD}=$ Ostochondrosis Dissecans). Osteokondroosimuutoksia arvioitiin myös sahausmenetelmällä, jossa reisiluun tai olkaluun distaalinen nivel (polvinivel tai kyynärnivel) sahattiin vannesahalla n. $12 \mathrm{~mm}$ siivuiksi. Siivujen sahauspinnoilta (a, b, c, d) osteokondroosivauriot luokiteltiin silmämääräisesti Etterlin ym. (2014) mukaan asteikolla 0-5, jossa luokka 0 tarkoittaa normaalia, vauriotonta siivupintaa ja luokassa 5 siivun pinnalla havaittavat vauriot ovat suuria ja laaja-alaisia.

Teurastamolta saatu oikea etusorkka säilytettiin pakastettuna ja etusorkan varvasluut (3. ja 4. metakarpaali) puhdistettiin myöhemmin ja niistä määritettiin paino, tilavuus, ominaispaino, murtolujuus ja tuhkapitoisuus. Ominaispaino määritettiin punnitsemalla luu ja luun syrjäyttämän veden määrä (Ogunbameru ym. 1990). Luun tilavuus laskettiin painosta ja ominaispainosta. Metakarpaalien murtolujuus mitattiin aineenkoestuskoneella (Lloyd Testing Instrument, Model 1000R) käyttäen 5000 N:n anturia. Mittausmenetelmä on muokattu Crenshawn ym. (1981) menetelmästä.

Tulosten tilastollinen analysointi tehtiin SAS-ohjelmiston MIXED-proseduurilla. Tilastollisessa mallissa oli kiinteinä tekijöinä jalostuslinjan ja sukupuolen vaikutus ja niiden yhdysvaikutus sekä satunnaistekijänä sikaerän, isän ja pahnueen ja pahnueen vaikutus hierarkkisesti isän alla. Alkupainoa käytettiin kovariaattina mallissa tuotanto-ominaisuuksissa ja ruhojen painoa käytettiin kovariaattina lihaprosentissa ja luun ominaisuuksissa. Residuaalien normaalisuus ja hajonta tarkistettiin. Koeryhmien välisiä eroja testattiin Tukeyn testillä, jos jalostuslinjan ja sukupuolen yhdysvaikutukset olivat tilastollisesti merkitseviä $(\mathrm{P}<0.05)$. Luokiteltujen muuttujien (nivelpintojen ja siivupintojen osteokondroosi luokka) jakaumien erilaisuutta eri jalostuslinjoissa tai eri sukupuolilla testattiin Khiin neliö -testillä. Testausta varten luokiteltuja tuloksia eri arvosteluluokissa yhdistettiin testauksen kannalta riittävän suuren havaintomäärän aikaansaamiseksi. Reisiluun molempien päiden ja olkanivelen nivelpinta-arvioinnin osteokondroosimuuosten luokkia yhdisteltiin siten, että normaali tai vähäinen muutos luokkaan yhdistettiin osteokondroosimuutosten arvosteluluokat 0 ja 1 ja vakava muutos luokkaan yhdistettiin arvosteluluokat 2-4. Polvinivelestä sahattujen siivujen korkein siivupistearvo luokkia yhdisteltiin siten, että luokka normaali tarkoitti arvosteluluokkaa 0, vähäinen muutos tarkoitti arvosteluluokkaa 1 ja vakava muutos luokkaan yhdistettiin arvosteluluokat 2-4. Testaukseen käytettiin SAS:n FREQ Proceduren versiota 9.4.

\section{Tulokset ja tulosten tarkastelu}

\section{Tuotantotulokset}

Eri jalostuslinjojen sikojen tuotantotuloksissa ei ollut merkitseviä eroja. Matriarkka- ja Muskelilinjojen siat kasvoivat keskimäärin 901 ja 870 g päivässä, rehuhyötysuhde oli 26.1 ja $25.8 \mathrm{MJ} \mathrm{NE} \mathrm{kg}^{-1}$ ja lihaprosentti 62.9 ja 63.5\% ( $\mathrm{P}>0.10$ ). Karjut kasvoivat hieman nopeammin kuin imisät (896 vs. 875 g pv-1, 
P>0.10), mutta imisien lihaprosentti oli hieman korkeampi kuin karjuilla (63.5 vs. 62.9\%). Rehuhyötysuhde oli karjuilla merkitsevästi $(\mathrm{P}<0.001)$ parempi kuin imisillä (25.4 vs. $\left.26.5 \mathrm{MJ} \mathrm{NE} \mathrm{kg}{ }^{-1}\right)$.

\section{Liikuntakyky}

Koesikojen jalkojen tarkastelu osoitti, että etujaloista virheettömiä oli $65 \%$ ja takajaloista $39 \%$. Yleisimmät rakenneviat koesikojen jaloissa olivat patit, sekä etu-, että takajaloissa (etujalat 16\%, takajalat 47\%). Seuraavaksi eniten esiintyi ventoja vuohisia etujaloissa ja takajalkojen ventoutta (12\% ja $8 \%)$. Liikuntakyvyssä ei ollut merkitsevää eroa eri jalostuslinjojen tai sukupuolten välillä (Taulukko 1). Main ym. (2000) ontumisen testauksessa oli tendenssi, että imisät saivat paremmat pisteet yksilön käyttäytyminen ryhmässä -osiossa kuin karjut $(\mathrm{P}<0.10)$. Yhdysvaikutuksia oli Mainin ym. (2000) testauksessa osioissa reagointi portin aukaisun jälkeen ja osiossa käynti. Matriarkkalinjan karjut olivat innokkaampia lähtemään karsinasta portin aukaisemisen jälkeen kuin Matriarkkalinjan imisät. Muskelilinjassa imisät olivat innokkaampia lähtemään karsinasta portin aukaisun jälkeen kuin karjut. Matriarkkalinjassa karjut saivat paremmat pisteet käynti -osiossa kuin imisät. Muskelilinjassa imisät saivat paremmat pisteet käynti -osiossa kuin karjut.

Taulukko 1. Jalostuslinjan ja sukupuolen vaikutus sikojen liikuntapisteisiin.

\begin{tabular}{|c|c|c|c|c|c|c|c|c|}
\hline & \multicolumn{2}{|c|}{ Jalostuslinja } & \multirow[b]{2}{*}{$\mathrm{P}$} & \multicolumn{2}{|c|}{ Sukupuoli } & \multirow[b]{2}{*}{ SEM } & \multicolumn{2}{|c|}{ Linja*sukup. } \\
\hline & Matriarkka & Muskeli & & Imisä & Karju & & $\mathrm{P}$ & $\mathrm{P}$ \\
\hline Liikuntakyky (asteikko 1-5) & 3.70 & 3.78 & & 3.83 & 3.64 & 0.129 & & \\
\hline $\begin{array}{l}\text { Käyttäytymis- ja kävelytestaus } \\
\text { (asteikko 0-5) }\end{array}$ & & & & & & & & \\
\hline Välitön reagointi ihmiseen & 1.14 & 1.01 & & 0.93 & 1.21 & 0.152 & & \\
\hline Käyttäytyminen ryhmässä & 0.60 & 0.58 & & 0.43 & 0.75 & 0.152 & 0 & \\
\hline Reagointi portin aukaisemisen & & & & & & & & \\
\hline jälkeen & 1.51 & 1.53 & & 1.47 & 1.58 & 0.169 & & $*$ \\
\hline Seisoma-asento & 0.67 & 0.55 & & 0.51 & 0.70 & 0.173 & & \\
\hline Käynti & 0.91 & 0.63 & & 0.79 & 0.74 & 0.144 & & 0 \\
\hline Kokonaisuus & 0.86 & 0.61 & & 0.67 & 0.80 & 0.135 & & \\
\hline
\end{tabular}

Merkitsevyydet: *** $(\mathrm{P}<0.001),{ }^{* *}(\mathrm{P}<0.01),{ }^{*}(\mathrm{P}<0.05)$ ja $0(\mathrm{P}<0.10)$.

\section{Osteokondroosi}

Karjujen reisiluut ja olkaluut olivat merkitsevästi painavampia kuin imisien luut (Taulukko 2). Jalostuslinjojen ja sukupuolten välillä oli reisiluun painossa yhdysvaikutus. Reisiluiden painoero oli suurempi Muskelilinjan sioilla kuin Matriarkkalinjan sioilla (424 ja 384 vs. 402 ja 395 g).

Taulukko 2. Reisiluiden ja olkaluiden painot jalostuslinjoittain ja sukupuolittain.

\begin{tabular}{|c|c|c|c|c|c|c|c|c|c|}
\hline & \multicolumn{2}{|c|}{ Jalostuslinja } & \multirow[b]{2}{*}{ SEM } & \multirow[b]{2}{*}{$\mathrm{P}$} & \multicolumn{2}{|c|}{ Sukupuoli } & \multirow[b]{2}{*}{ SEM } & \multirow[b]{2}{*}{$\mathrm{P}$} & \multirow{2}{*}{$\begin{array}{c}\text { Linja*sukup. } \\
\mathrm{P} \\
\end{array}$} \\
\hline & Matriarkka & Muskeli & & & Imisä & Karju & & & \\
\hline \multicolumn{10}{|l|}{ Paino } \\
\hline Reisiluu, kpl & 59 & 52 & & & 55 & 56 & & & \\
\hline Reisiluu, $\mathrm{g}^{\mathrm{\alpha}}$ & 399 & 408 & 7.2 & & 390 & 417 & 7.5 & $* * *$ & $*$ \\
\hline Olkaluu, kpl & 44 & 40 & & & 53 & 31 & & & \\
\hline Olkaluu, ga & 353 & 357 & 6.0 & & 337 & 373 & 6.0 & $* * *$ & \\
\hline
\end{tabular}

${ }^{\mathrm{a}}$ Nettopainoa on käytetty kovariaattina. Merkitsevyydet: *** $(\mathrm{P}<0.001),{ }^{* *}(\mathrm{P}<0.01),{ }^{*}(\mathrm{P}<0.05)$ ja $0(\mathrm{P}<0.10)$.

Lonkkanivelen nivelpintojen osteokondroosimuutoksien jakaumissa ei ollut eroa jalostuslinjojen tai sukupuolten välillä. Polvinivelessä osteokondroosimuutosten jakauma oli suuntaa antavasti $(\mathrm{P}<0.10)$ erilainen imisillä ja karjuilla, siten että imisillä oli enemmän vakavia osteokondroosimuutoksia polvinivelessä (Taulukko 3). Kyynärnivelen nivelpintojen osteokondroosimuutoksien jakaumissa ei ole merkitsevää eroa jalostuslinjojen tai sukupuolten välillä, mutta karjuilla oli määrällisesti enemmän vaikeita osteokondroosimuutoksia kuin imisillä (30.0\% vs. 20.8\%).

Polvinivelen siivujen osteokondroosin esiintyvyydessä ei ollut eroa jalostuslinjojen välillä, mutta karjujen osteokondroosimuutosten jakauma poikkesi merkitsevästi imisien osteokondroosimuutosten jakaumasta $(\mathrm{P}<0.05)$. Karjuilla vakavampia osteokondroosimuutoksia oli enemmän kuin imisillä (Taulukko 4). Kyynärnivelen sahaussiivujen jakaumissa ei ollut merkitseviä eroja jalostuslinjojen tai 
sukupuolien välillä. Kyynärnivelen sahaussiivuissa vaikeita osteokondroosimuutoksia oli prosentuaalisesti enemmän karjuilla kuin imisillä (25.8 vs. 17.0\%). Olkaluita oli kuitenkin vähemmän kuin reisiluita, joten ehkä myös sen vuoksi sukupuolten välille ei saa merkitsevää eroa.

Taulukko 3. Reisiluun ja olkaluun proksimaalisen ja distaalisen nivelpinta-arvostelun osteokondroosivaurioiden jakaantuminen jalostuslinjoittain ja sukupuolittain.

\begin{tabular}{|c|c|c|c|c|c|}
\hline & \multicolumn{4}{|c|}{ Osteokondroosimuutosten luokittelu } & \multirow{3}{*}{$\begin{array}{c}\text { Khiin neliö } \\
\text { P }\end{array}$} \\
\hline & \multicolumn{2}{|c|}{ Normaali tai vähäinen } & \multicolumn{2}{|c|}{ Vakava } & \\
\hline & $\mathrm{kpl}$ & $\%$ & $\mathrm{kpl}$ & $\%$ & \\
\hline \multicolumn{6}{|l|}{ Lonkkanivel } \\
\hline Matriarkka & 35 & 59.3 & 24 & 40.7 & \\
\hline Muskeli & 35 & 67.3 & 17 & 32.7 & \\
\hline Imisät & 32 & 58.2 & 23 & 41.8 & \\
\hline Karjut & 38 & 67.9 & 18 & 32.1 & \\
\hline \multicolumn{6}{|l|}{$\underline{\text { Polvinivel }}$} \\
\hline$\overline{\text { Matriarkka }}$ & 31 & 52.5 & 28 & 47.5 & \\
\hline Muskeli & 25 & 49.0 & 26 & 51.0 & \\
\hline Imisät & 23 & 42.6 & 31 & 57.4 & \\
\hline Karjut & 33 & 58.9 & 23 & 41.1 & 0 \\
\hline \multicolumn{6}{|l|}{ Olkanivel } \\
\hline$\overline{\text { Matriarkka }}$ & 26 & 59.1 & 18 & 40.9 & \\
\hline Muskeli & 22 & 56.4 & 17 & 43.6 & \\
\hline Imisät & 30 & 57.7 & 22 & 42.3 & \\
\hline Karjut & 18 & 58.1 & 13 & 41.9 & \\
\hline
\end{tabular}

Merkitsevyydet: *** $(\mathrm{P}<0.001)$, ** $(\mathrm{P}<0.01), *(\mathrm{P}<0.05)$ and $0(\mathrm{P}<0.10)$.

Taulukko 4. Sahatun polvinivelen siivujen suurimman osteokondroosivaurion jakaantuminen sukupuolittain ja jalostuslinjoittain.

\begin{tabular}{|c|c|c|c|c|c|c|c|}
\hline & \multicolumn{6}{|c|}{ Osteokondroosimuutosten luokittelu } & \multirow{3}{*}{$\begin{array}{c}\text { Khiin neliö } \\
\text { P }\end{array}$} \\
\hline & \multicolumn{2}{|c|}{ Normaali } & \multicolumn{2}{|c|}{ Vähäinen } & \multicolumn{2}{|c|}{ Vakava } & \\
\hline & $\mathrm{kpl}$ & $\%$ & $\mathrm{kpl}$ & $\%$ & $\mathrm{kpl}$ & $\%$ & \\
\hline \multicolumn{8}{|l|}{ Polvinivel } \\
\hline Matriarkka & 15 & 25.4 & 24 & 40.7 & 20 & 33.9 & \\
\hline Muskeli & 11 & 21.2 & 23 & 44.2 & 18 & 34.6 & \\
\hline Imisät & 14 & 25.5 & 29 & 52.7 & 12 & 21.8 & \\
\hline Karjut & 12 & 21.4 & 18 & 32.1 & 26 & 46.4 & $*$ \\
\hline
\end{tabular}

Merkitsevyydet: *** $(\mathrm{P}<0.001)$, ** $(\mathrm{P}<0.01), *(\mathrm{P}<0.05)$ ja $0(\mathrm{P}<0.10)$.

\section{Metakarpaalit}

Tässä kokeessa metakarpaalien murtolujuus oli huomattavasti suurempi kuin aiemmissa kokeissa (Karhapää ym. 2009, Partanen ym. 2010). Kornegay ym. (1977) mukaan karjujen kasvu on nopeampaa ja rehuhyötysuhde parempi, jos rehuissa käytetään kalsium- ja fosforipitoisuutta, joka ylittää NRC suositusarvot 25\%. Tässä kokeessa rehuista analysoitu keskimääräinen kalsiumpitoisuus oli noin 25\% suurempi ja sulavan fosforin pitoisuus keskimäärin 30\% suurempi kuin ruokintasuosituksissa. Myös rehujen suunniteltu keskimääräinen D-vitamiinipitoisuus oli noin 46\% suurempi kuin ruokintasuosituksissa. Monissa tutkimuksissa on todettu, että rehun kalsium ja fosforipitoisuuden nostaminen lisää luiden murtolujuutta (Nimmo ym. 1980). Crenshaw ym. (1981) tutkimuksessa kalsium ja fosforipitoisuuden nostaminen paransi luiden lujuutta ja tuhkapitoisuutta. Käänteen (1983) tutkimuksessa kolmannen metakarpaalin tuhkapitoisuus oli suurempi maatiaisrodun sioilla, jotka saivat kalsiumpitoisuudeltaan korkeampaa rehua.

Karjujen metakarpaalit olivat merkitsevästi painavampia (30.2 vs. 27.5 g, $\mathrm{P}<0.001$ ) ja kooltaan suurempia kuin imisien (22.6 vs. $20.4 \mathrm{~cm}^{3}$, P<0.001) metakarpaalit (Taulukko 5). Myös karjujen metakarpaalien murtolujuus merkitsevästi suurempi kuin imisillä (164 vs. 151 kg- cm, P<0.01). Karjujen metakarpaalien tuhkapitoisuus oli kuitenkin pienempi (31.0 vs. $32.2 \%, \mathrm{P}<0.001)$ kuin imisillä. Karjujen metakarpaalien ominaispaino oli suuntaa antavasti pienempi kuin imisillä (1.34 vs. $\left.1.35 \mathrm{~g} \mathrm{~cm}^{3-1}, \mathrm{P}<0.10\right)$. Vastaavia havaintoja on tehty aikaisemmissa tutkimuksissa (Cromwell ym. 1970, Crenshaw ym. 1981). Jalostuslinjan ja sukupuolen välillä ei ollut yhdysvaikutuksia. 
Taulukko 5. Jalostusvalinnan ja sukupuolen vaikutukset metakarpaalien (3. ja 4.) ominaisuuksiin.

\begin{tabular}{|c|c|c|c|c|c|c|c|c|}
\hline & \multicolumn{2}{|c|}{ Jalostuslinja } & \multirow[b]{2}{*}{ SEM } & \multirow[b]{2}{*}{$\mathrm{P}$} & \multicolumn{2}{|c|}{ Sukupuoli } & \multirow[b]{2}{*}{ SEM } & \multirow[b]{2}{*}{$\mathrm{P}$} \\
\hline & Matriarkka & Muskeli & & & Imisä & Karju & & \\
\hline Metakarpaalipareja, kpl & 74 & 61 & & & 62 & 73 & & \\
\hline III ja IV metakarpaali ka. & & & & & & & & \\
\hline Paino, g & 29.1 & 28.7 & 0.59 & & 27.5 & 30.2 & 0.58 & $* * *$ \\
\hline Pituus, mm & 78.0 & 76.8 & 0.93 & & 78.0 & 76.9 & 0.93 & \\
\hline Paksuus, mm & 14.1 & 14.3 & 0.13 & & 13.8 & 14.7 & 0.13 & $* * *$ \\
\hline Tilavuus, $\mathrm{cm}^{3}$ & 21.5 & 21.5 & 0.43 & & 20.4 & 22.6 & 0.42 & $* * *$ \\
\hline Ominaispaino, g cm-1 & 1.35 & 1.34 & 0.01 & & 1.35 & 1.34 & 0.01 & o \\
\hline Murtolujuus, kg-cm & 159 & 156 & 3.3 & & 151 & 164 & 3.2 & $* *$ \\
\hline Tuhka, DM \% & 31.6 & 31.6 & 0.29 & * & 32.2 & 31.0 & 0.31 & $* * *$ \\
\hline
\end{tabular}

\section{Verinäytteet}

Seerumin kokonaiskalsiumpitoisuus ja epäorgaanisen fosforin ja alkalisen fosfataasin pitoisuudet ovat samaa luokkaa kuin aikaisemmissa tutkimuksissa Boyd ym. (1983), Kääntee (1983) ja O’Doherty ym. (2010). Matriarkkalinjan sikojen veren seerumissa oli merkitsevästi $(\mathrm{P}<0.05)$ enemmän kokonaiskalsiumia kuin Muskelilinjan sikojen seerumissa (taulukko 6). Imisien veren seerumin kalsiumpitoisuus oli merkitsevästi suurempi kuin karjuilla $(\mathrm{P}<0.01)$. Muskelilinjan sioilla ero sukupuolten välillä oli suurempi kuin Matriarkkalinjan sioilla (2.84 ja 2.73 vs. 2.85 ja 2.82). Seerumin kalsiumpitoisuudessa oli merkitsevä yhdysvaikutus jalostuslinjan ja sukupuolen välillä $(\mathrm{P}<0.05)$. Matriarkkalinjassa ero sukupuolien välillä ei ollut merkitsevä, mutta Muskelilinjassa seerumin kalsiumpitoisuus oli merkitsevästi pienempi karjuilla kuin imisillä $(\mathrm{P}<0.001)$.

Sikojen seerumin alkalisen fosfataasin aktiivisuutta on aikaisemmissa tutkimuksissa käytetty luunmuodostuksen merkkiaineena. Seerumin alkalisen fosfataasin pitoisuus heijastaa luuston mineraalisen aineenvaihdunnan voimakkuutta ja se on aikaisemmissa kokeissa ollut positiivisessa korrelaatiossa luusolujen aktiivisuuden, kalsiumin aineenvaihdunnan ja luunmuodostusprosessin spesifisten merkkiaineiden kanssa (Boyd ym. 1983). Tässä kokeessa alkalisen fosfataasin aktiivisuus oli määrällisesti korkeampi karjuilla ja Muskelilinjan sioilla kuin imisillä tai Matriarkkalinjan sioilla (134.2 ja 132.9 vs. 124.2 ja $125.4 \mathrm{U} \mathrm{l}^{-1}$, Taulukko 6).

Taulukko 6. Jalostusvalinnan ja sukupuolen vaikutus koesikojen seerumin kalsiumin, epäorgaanisen fosforin, alkalisen fosfataasin ja D-vitamiini pitoisuuteen.

\begin{tabular}{|c|c|c|c|c|c|c|c|c|}
\hline & \multicolumn{2}{|l|}{ Jalostuslinja } & \multirow[b]{2}{*}{$\mathrm{P}$} & \multicolumn{2}{|c|}{ Sukupuoli } & \multirow[b]{2}{*}{ SEM } & \multirow[b]{2}{*}{$\mathrm{P}$} & \multirow{2}{*}{$\begin{array}{l}\text { Linja*sukup. } \\
\mathrm{P}\end{array}$} \\
\hline & Matriarkka & Muskeli & & Imisä & Karju & & & \\
\hline $25-\mathrm{OH} \mathrm{D}_{3}$ vitamiini nmol l-1 & 42.8 & 44.4 & & 43.4 & 43.8 & 1.49 & & \\
\hline Alkalinen fosfataasi $\mathrm{U}^{-1 \not}$ & 125.4 & 132.9 & & 124.2 & 134.2 & 5.77 & & \\
\hline Kalsium mmol $\mathrm{l}^{-1 a}$ & 2.84 & 2.79 & $*$ & 2.85 & 2.78 & 0.026 & $* *$ & $*$ \\
\hline Fosfori mmol l ${ }^{-1}$ & 2.87 & 2.96 & & 2.91 & 2.93 & 0.062 & & \\
\hline
\end{tabular}

Tässä tutkimuksessa seerumin D3 vitamiini pitoisuuksissa (S-25-OH-D3) ei ollut merkitseviä eroja jalostuslinjojen tai sukupuolien välillä (Taulukko 6). D3 vitamiinipitoisuudet vaihtelivat välillä 42.8-44.4 nmol l-1. Käänteen (1983) tutkimuksessa S-25-OH-D3-keskiarvot olivat paljon korkeammat kuin tässä kokeessa. S-25-OH-D3: $\mathrm{n}$ arvot kokeen lopussa kokeessa vaihtelivat välillä 37.5-37.9 $\mu \mathrm{g} \mathrm{l}^{-1}$ (93.6-94.6 nmol $\left.l^{-1}\right)$.

\section{Johtopäätökset}

Tämän tutkimuksen perusteella suomalaisilla maatiaisrodun sioilla on paljon ostekondroosiin viittaavia vaurioita reisiluiden ja olkaluiden nivelissä. Suurin osa muutoksista oli kuitenkin lieviä ja vakavia muutoksia oli lähinnä vain kyynärnivelessä. Nivelpintojen arviointimenetelmää käytettäessä osteokondroosin esiintymisessä ei havaittu eroja kahden jalostuslinjan tai kahden sukupuolen välillä. 
Sahausmenetelmää käytettäessä osteokondroosin esiintymisessä ei ollut eroja jalostuslinjojen välillä, mutta oikean polvinivelen sahaussiivujen osteokondroosiin viittaavien muutosten jakauma oli merkitsevästi $(\mathrm{P}<0.05)$ erilainen karjuilla ja imisillä. Karjuilla vakavat osteokondroosimuutokset olivat yleisempiä kuin imisillä. Sahausmenetelmää käytettäessä ostokondroosiin viittaavia muutoksia (luokat 1-5) polvinivelessä tai kyynärnivelessä oli vähemmän kuin nivelpintojen arviointimenetelmää käytettäessä (70.0-71.4 vs. 85-99\%).

\section{Kirjallisuusluettelo}

Boyd, R.D., Hall, D. \& Wu, J.F. 1983. Plasma alkaline phosphatase as a criterion for determining biological availability of phosphorus for swine. Journal of Animal Science 57: 396-401.

Busch, M.E. \& Wachmann, H. 2011. Osteochondrosis of the elbow joint in finishing pigs from three herds: Associations among different types of joint changes and between osteochondrosis and growth rate. The Veterinary Journal 188: 197-203.

Crenshaw, T.D., Peo, E.R., Lewis, A.J., Moser, B.D. \& Olson, D. 1981. Influence of age, sex and calcium and phosphorus levels on the mechanical properties of various bones in swine. Journal of Animal Science 52: 13191329.

Cromwell, G.L., Hays, V.W., Chaney, C.H. \& Overfield, J.R. 1970. Effects of dietary phosphorus and calcium level on performance, bone mineralization and carcass characteristics of swine. Journal of Animal Science 30: 519-525.

Daly, J.A. \& Ertigshausen, G. 1972. Direct method for determining inorganic phosphate in serum with the "CentrifiChem". Clinical Chemistry 18: 263-265.

Etterlin, P.E., Ytrehus, B., Lundeheim, N., Heldmer, E., Osterberg, J. \& Ekman, S. 2014. Effects of freerange and confined housing on joint health in a herd of fattening pigs. BMC Veterinary Research 10: 208.

IFCC 1983/4: IFCC Methods for the Measurement of Catalytic Concentration of Enzymes, Part 5. IFCC Method for Alkaline Phosphatase (orthophosphoric-monoesterphosphohydrolase, alkaline optimum, EC 3.1.3.1). Journal of Clinical Chemistry and Clinical Biochemistry 21: 731-748.

Janssen, J. \& Helbing, A.R. 1991. Arsenazo III: An improvement of the routine calcium determination in serum. European Journal of Clinical Chemistry and Clinical Biochemistry 29: 197-201.

Jensen, T.B. \& Toft, N. 2009. Causes of and predisposing risk factors for leg disorders in growing-finishing pigs. CAB Reviews: Perspectives in Agriculture, Veterinary Science, Nutrition and Natural Resources 4: 1-8.

Jørgensen, B. \& Andersen, S. 2000. Genetic parameters for osteochondrosis in Danish Landrace and Yorkshire boars and correlations with leg weakness and production traits. Animal Science 71: 427-434.

Karhapää, M., Partanen, K. \& Ylivainio, K. 2009. Is phytase supplementation necessary when finishing pigs are fed diets that contain no monocalsium phosphate? Animal performance, bone strength, and environmental impact. 39 s. (Raportti 14.12.2009).

Kääntee, E. 1983. Effects of Ca and P levels in the feed on serum calcium, phosphorus, alkaline phosphatase, hydroxyproline and 25-hydroxycholecalciferol levels, and on the ash content of the third metacarpal bone in pigs. Nordisk Veterinaermedicin 35: 273-86.

Main, D.C.J., Clegg, J., Spatz, A. \& Green, L.E. 2000. Repeatability of a lameness scoring system for finishing pigs. Veterinary Record 147: 574-576.

Nakano, T., Brennan, J.J. \& Aherne, F.X. 1987. Leg weakness and osteochondrosis in swine: a review. Canadian Journal of Animal Science 67: 883-901.

Nalon, E., Conte, S., Maes, D., Tuyttens, F.A.M. \& Devillers, N. 2013. Assessment of lameness and claw lesions in sows. Livestock Science 156: 10-23.

Nimmo, R.D., Peo, E.R., Moser, B.D., Cunningham, P.J. Olson, D.G. \& Crenshaw, T.D. 1980. Effect of various levels of dietary calcium and phosphorus on performance, blood, and bone parameters in growing boars. Journal of Animal Science 51: 100-104.

O'Doherty, J.V., Gahan, D.A., O'Shea, C., Callan, J.J. \& Pierce, K.M. 2010. Effects of phytase and 25-hydroxyvitamin D3 inclusions on the performance, mineral balance and bone parameters of grower-finisher pigs fed low-phosphorus diets. Animal 4: 1634-1640.

Ogunbameru, B.O., Evans, J.L. \& Kornegay, E.T. 1990. Technique for the determination of bone volume and specific gravity. Canadian Journal of Animal Science 70: 1137.

Partanen, K., Siljander-Rasi, H., Karhapää, M., Ylivainio, K. \& Tupasela, T. 2010. Responses of Responses of growing pigs to different levels of dietary phosphorus-Performance, bone characteristics, and solubility of faecal phosphorus. Livestock Science 134: 109-112.

Reiland, S. 1975. Osteochondrosis in the Pig: A Morphologic and Experimental Investigation with Special Reference to the Leg Weakness Syndrome. Stockholm, Sweden: Akademisk Avhandling.

SAS 2000. SAS OnlineDoc ${ }^{\circledR}$ Version 8. 
Serenius, T., Sevón-Aimonen, M.-L. \& Mäntysaari, E.A. 2001. The genetics of leg weakness in Finnish Large White and Landrace populations. Livestock Production Science 69: 101-111.

Storskrubb, A., Sevón-Aimonen, M.-L. \& Uimari, P. 2010. Genetic parameters for bone strength, osteochondrosis and meat percentage in Finnish Landrace and Yorkshire pigs. Animal 4: 1319-1324.

van Grevenhof, E.M., Ott, S., Hazeleger, W., van Weeren, P.R., Bijma P. \& Kemp, B. 2011. The effects of housing system and feeding level on the joint-specific prevalence of osteochondrosis in fattening pigs. Livestock Science 135: 53-61.

Ytrehus, B., Carlson, C.S. \& Ekman, S. 2007. Etiology and pathogenesis of osteochondrosis. Veterinary Pathology 44: 429-448. 